\title{
Proceedings of the Tenth Annual UT-ORNL-KBRIN Bioinformatics Summit 2011
}

\author{
Eric C Rouchka ${ }^{1 *}$, Robert M Flight ${ }^{2}$, Ramin Homayouni ${ }^{3}$ \\ From 10 ${ }^{\text {th }}$ Annual UT-ORNL-KBRIN Bioinformatics Summit 2011 \\ Memphis, TN, USA. 1-3 April 2011
}

The University of Tennessee (UT), the Oak Ridge National Laboratory (ORNL), and the Kentucky Biomedical Research Infrastructure Network (KBRIN), have collaborated over the past decade to share research and educational expertise in bioinformatics. One result of this collaboration is the joint sponsorship of an annual regional summit to bring together researchers, educators and students who are interested in bioinformatics from a variety of research and educational institutions. This summit provides unique opportunities for collaboration and forging links between members of the various institutions. This year, the Tenth Annual UT-ORNL-KBRIN Bioinformatics Summit was held at the University of Memphis in Memphis, Tennessee from April 1-3, 2011. A total of 225 participants pre-registered for the summit, with 146 from various Tennessee institutions and 60 from various Kentucky institutions. A number of additional participants came from universities and research institutions from other states and countries, e. g. University of Arkansas Medical Sciences, University of British Columbia, University of Cincinnati, Iowa State University, etc. Seventy-four registrants were faculty, with an additional 73 students, 50 staff, and 28 postdoctoral participants.

The conference program consisted of three days of presentations. The first day included a pre-summit of talks by researchers supported by the Kentucky Biomedical Research Infrastructure Network (KBRIN), and three workshops covering the topics Next-Generation Sequencing, the workflow platform Galaxy, and GeneMANIA. The next two days were dedicated to scientific presentations divided into three plenary sessions on Pediatric Genetics, Pharmacogenomics and Systems

\footnotetext{
* Correspondence: eric.rouchka@louisville.edu

'Department of Computer Engineering and Computer Science, University of Louisville, Duthie Center for Engineering, Louisville, KY 40292, USA Full list of author information is available at the end of the article
}

Biology. Each session also included short talks selected from the submitted poster abstracts.

\section{Pre-summit KBRIN session}

Dr. Eric Rouchka started the pre-summit KBRIN session with an update on the supplement to the primary KBRIN grant awarded in 2009. Thanks to the funding provided by the supplement, five postdoctoral research associates have been hired, along with two masters level bioinformatics staff positions. In addition, a weekly seminar series has been implemented that includes externally invited speakers with strong research programs in bioinformatics.

Following was a series of short talks from various University of Louisville researchers: "Developing an Analysis Pipeline for FT-ICR-MS Isotopologue Data from Stable Isotope Resolved Metabolomics (SIRM) Experiments" (Hunter Moseley), "Time Series Classifier Model for miR-mRNA Relationships" (Jovan D. Rebolledo-Mendez), "Assessing Variations in NGS Data" (Alex Kemper), "A Systems Based Approach to Find Protein Interactions Across Tissues" (Fahim Mohammad), "categoryCompare: High-Throughput Data Meta-Analysis Using Gene Annotations" (Robert M. Flight), "Collaborations between Biology/Bioinformatics" (Benjamin J. Harrison).

\section{Friday workshops}

Jon Armstrong of Cofactor Genomics (St. Louis, MO; http://www.cofactorgenomics.com) started the official summit program with an excellent overview of the past, present and future of DNA sequencing, beginning with the Maxam-Gilbert [1] and Sanger [2] methods and transitioning to the approaches used by next-generation sequencers. Among the technologies covered were pyrosequencing [3], reversible dye terminator technology [4], sequencing by ligation [5], and single molecule real time 
sequencing [6]. As Jon walked through each of the technologies, he also sought to explain what types of experiments are best suited for each NGS platform, based on the strengths and weaknesses of each technology. Given the rapidly growing number of NGS machines available, the information was extremely useful for both those planning NGS experiments and those analyzing the resulting data.

Following up, Dr. James Taylor from Emory University gave a workshop on the workflow system GALAXY $[7,8]$. Dr. Taylor started with a comprehensive explanation of the many research issues motivating the development of GALAXY as an easily modifiable, reproducible workflow system for both biologists and bioinformaticians working with high-throughput data. He then proceeded to explain and demonstrate many of GALAXY's features by performing real world analyses using data from the UCSC genome browser [9]. Notable features include the ability to share workflows with others, the ability to generate results pages (similar to full blown publications) with workflows embedded in the document and accessible to anyone viewing the page, and the recent ability for NGS core lab implementations to couple sample requests to workflows so that data processing can occur as soon as the data becomes available. As a final note, Dr. Taylor also demonstrated how easy it is to set up GALAXY instances in Amazons EC2 cloud computing system, enabling one to take advantage of cloud computing systems [10].

The final workshop was given by Dr. Quaid Morris from the University of Toronto on the use of GeneMANIA [11] for pathway and network analysis. GeneMANIA uses gene association networks to assign probable functions of genes based on guilt by association: those genes that share connections (annotations or interactions) probably share other attributes as well. GeneMANIA is available either as a Cytoscape plugin $[12,13]$ or on the web.

\section{Session I: pediatric genetics}

The first session began with opening remarks by Dr. Ramin Homayouni from the University of Memphis. Dr. Homayouni provided a 10 year retrospective of the summit, its beginnings and growth, and the many collaborations and new bioinformatic tools that have resulted from those attending the conference.

The Pediatric Genetics session was truly underway with Dr. Hakon Hakonarson of The Children's Hospital of Philadelphia discussing his research on determining the genetic underpinnings of complex pediatric disorders. As a way to try and cope with the large number of rare genetic variants and their combinations that lead to disease, his group at the Center for Applied Genomics at Children's Hospital of Philadelphia (CHOP) is targeting to genotype 100,000 children over a five year period making use of a biorepository. One of the goals of this project is to link the genotypes to electronic health care records for the purpose of tying together genotype and phenotype information. Using this data, they have determined SNPs involved in a number of different diseases, including juvenile (Type I) diabetes [14-27], neuroblastoma [28-30] and autism spectrum disorder [31-35]. They hope to be able to use this as a retrospective tool to determine the causes of many other diseases as well.

Following up on that, Dr. Jun Yang from St. Jude Children's Research Hospital presented work on pharmacogenomics and racial disparities in childhood acute lymphoblastic leukaemia [36]. Especially compelling was the ability to use a set of genome wide SNPs to define racial ancestry. These same SNPs also provided a large amount of power in explaining a child's probability of survival of ALL. In addition to measuring the overall survival probability, Dr. Yang discussed how this information is being used to predict relapse and response to five drugs: DNA, ASP, Chcb, AraC, and 6-TG.

\section{Session II: pharmacogenomics}

Starting the session on pharmacogenomics, Dr. Josh Denny from Vanderbilt University presented work on using electronic medical records for discovery and validation in genome science as part of the eMERGE Network [37]. His group has concentrated on coupling Vanderbilt's opt-out biobank where samples are genotyped for high-value SNPs, with phenotypes generated through text-mining of associated electronic medical records. Specifically, Dr. Denny has interest in genotyping SNPs in 10,000 samples across 21 loci implicated in atrial fibrulation, Crohn's disease, type II diabetes, multiple sclerosis, and rheumatoid arthritis. Highlighted challenges in using electronic medical records were presented, included the diagnosis of diseases for which treatment is covered by insurance but which the patient did not have, and the use of templates in doctor's offices that result in non-informative field descriptions [38]. Both of these proved to be difficult for natural language processing. Dr. Denny discussed case studies of using the Vanderbilt Electronic Systems for Pharmacogenomic Assessment (VESPA) to determine SNPs associated both with disease and pharmacogenomic outcomes [39].

Dr. Ursula Amstutz of the University of British Columbia presented work from the Canadian Pharmacogenomics Network for Drug Safety focusing on reducing drug harm in children [40]. The current process of validating drug safety looks at evidence for drug efficacy and safety at usual doses in populations; however physicians treat individuals, who may have different reactions to a given drug. When adverse drug effects in children 
are considered, the picture becomes more complicated, due to differences in drug metabolism compared to adults. Working with children who experience cisplatin induced hearing loss, they were able to identify two SNPs that predicted $48 \%$ of the cases of hearing loss [41]. Another study examined anthracycline induced cardiotoxicity, finding a highly significant SNP that was validated in a separate group of patients [42]. It is hoped that identification of these SNPs will lead to preemptive testing to provide guidance in choosing methods of treatment for children.

\section{Session III: systems biology}

Quaid Morris from the University of Toronto led the final plenary session with a talk titled "Three Degrees of Propagation for Predicting Gene Function Using Networks." In this presentation, Dr. Morris discussed the idea that biological interaction networks are in general "small world" networks with a high degree of hubs and short paths connecting most nodes. Using the knowledge that often genes in the same pathway are more likely to share neighbors than to be directly connected, gene function can be better predicted from functional gene and interaction networks by considering shared neighbors. Dr. Morris' group observed that in general, only three to four degrees of propagation provides useful information when considering true gene interactions. After that, every gene in a gene network study is likely to be visited, much in the same way that the idea of "six degrees of separation" is able to link together any two different individuals worldwide within six steps, on average, through "a friend of a friend" relationships [43]. This is the process found in the "Kevin Bacon game" in which participants are challenged to link a random actor or actress to Kevin Bacon in six or fewer steps where two actors/actresses are connected if they appeared in a movie or commercial together [44]. The Morris group has created a new algorithmic approach, 3Prop, which takes this neighborhood information into account to predict gene function. 3Prop extends their previous work of predicting gene function given limited annotation information $[11,45]$. This approach has been applied to identify the gender of users of social media sites by positively weighting their friends' genders and negatively weighting their friends' friends' genders.

The second talk of the session was the final plenary speaker, David Galas, from the Institute for Systems Biology who presented "Genetics in the Age of Sequencing: Converging on Complexity." In this talk, Dr. Galas discussed the transformation of human genetics as a result of whole genome sequencing and associated computational approaches. A discussion ensued about the advances that genome wide association studies (GWAS) have led into the understanding of complex diseases [46] , including 1212 published genome-wide associations for 210 traits as of 12/2010 (http://www.genome. gov/gwastudies). However, the point was made that familial-based sequencing can be a powerful technology for complex disease association, as demonstrated by a family of four sequencing project in which two siblings and their parents were sequenced [47]. Dr. Galas discussed the results of this project which was based on two recessive Medalian disorders displayed in the siblings: Miller syndrome and primary ciliary dyskinesia. By looking at familial sequencing, the ability to detect recombination events with high precision is possible, which can lead to more directed analysis of disorders at a genetic level. Dr. Galas expanded upon additional current research at the Institute for Systems Biology, including a multigenerational sequencing project and a project to sequence 600 individuals (all in families) focusing on diseases such as Huntington's and congenital heart defects.

\section{Posters and short talks}

The poster session was held on day two before the main banquet. Forty-eight posters were on display, all from a variety of different research areas. A number of posters were also selected for short talks in each session. The talks and the presenting authors are listed below for each session. For full author lists and abstracts see the rest of the supplement.

\section{Session I}

"Contribution of common and rare variants in SLCO1B1 to variation in clearance of methotrexate in acute lymphoblastic leukemia patients" (Laura B. Ramsey, St. Jude Children's Research Hospital), "Significant Analysis of Microarray Using Literature (SAMUL)" (Ramin Homayouni, University of Memphis), "Integrating RNASeq data Improves Protein Identification in Shotgun Proteomics" (Xiaojing Wang, Vanderbilt University), "The Challenges and Opportunities Facing us as we Organize Genetic Research Data for "Meaningful Use"” (Ted Kalbfleisch, Intrepid Bioinformatics).

\section{Session II}

"Integrative Biclustering of Heterogeneous Datasets using a Bayesian Nonparametric Model with Application to Chemogenomics" (Dazhuo Li, University of Louisville), "A Statistical Procedure to Evaluate Agreement of Differential Expression for Translational Cross-Species Genomics" (Cuilan Gao, St. Jude Children's Research Hospital), "Utility of Methylation Biomarkers in Complex Disease" (Gary L Rogers, University of Tennessee Knoxville), "Targeted Genotyping for Biomarker Development" (Bradford Silver, Computable Genomix). 


\section{Session III}

"Identify the Key Genes and Pathways in the Progression of Hepatitis C Virus Induced Hepatocellular Carcinoma Using a Systems Biology Approach" (Siyuan Zheng, Vanderbilt University), "Bioinformatics Analysis of Genome-Wide Differential Gene Expression Patterns Associated with Differential Susceptibility to Severe Group A Streptococcal Sepsis" (Nourtan Abdeltawab, University of Tennessee Health Science Campus), "Genes Without Borders: A Systematic Survey of Mobile Genes and Genomes in Environmental Metagenomes" (Ramy Aziz, San Diego State University), "Design, Implementation and Uses of the Parabiclique Algorithm" (Charles A. Phillips, University of Tennessee Knoxville).

\section{Future plans}

The 2012 Bioinformatics summit will return to the state of Kentucky in the spring of 2012. Potential focus areas include current technological trends in molecular biology, applications of next-generation sequencing, and systems biology.

\begin{abstract}
Acknowledgements
We would like to thank the additional Conference Program Committee members Nigel Cooper (University of Louisville), Dan Goldowitz (University of British Columbia), Julia Krushkal (University of Tennessee-Memphis), Mike Langston (University of Tennessee-Knoxville), Terry Mark-Major (University of Tennessee-Memphis), Cynthia Peterson (University of Tennessee-Knoxville), Claire Rinehart (Western Kentucky University) Arnold Stromberg (University of Kentucky), Rob Williams (University of Tennessee-Memphis) and Zhongming Zhao (Vanderbilt University) for organizing an outstanding scientific program. In addition, we wish to thank Stephanie Dearing, Terry Mark-Major, Michelle Padgett, Donna Schulte and Jane Thornton for all of their efforts in dealing with the conference organization details. Funding for the UT-ORNLKBRIN Summit is provided in part by the University of Memphis Office of the Provost, Memphis Research Consortium, Kentucky Biomedical Research Infrastructure Network (KBRIN), University of Tennessee Center for Integrative and Translational Genomics, University of Tennessee Molecular Resource Center, UT-ORNL Science Alliance, and NIH grant P20RR16481.
\end{abstract}

\section{Author details}

${ }^{1}$ Department of Computer Engineering and Computer Science, University of Louisville, Duthie Center for Engineering, Louisville, KY 40292, USA. ${ }^{2}$ Department of Anatomical Sciences and Neurobiology, University of Louisville, Louisville, KY 40292, USA. ${ }^{3}$ Department of Biological Sciences, University of Memphis, Memphis, TN 38152, USA.

Published: 5 August 2011

\section{References}

1. Maxam AM, Gilbert W: A new method for sequencing DNA. Proc Natl Acad Sci U S A 1977, 74:560-564.

2. Sanger F, Nicklen $S$, Coulson AR: DNA sequencing with chain-terminating inhibitors. Proc Natl Acad Sci U S A 1977, 74:5463-5467.

3. Margulies M, Egholm M, Altman WE, Attiya S, Bader JS, Bemben LA, Berka J, Braverman MS, Chen YJ, Chen Z, Dewell SB, Du L, Fierro JM, Gomes XV, Godwin BC, He W, Helgesen S, Ho CH, Irzyk GP, Jando SC, Alenquer ML, Jarvie TP, Jirage KB, Kim JB, Knight JR, Lanza JR, Leamon JH, Lefkowitz SM, Lei M, Li J, Lohman KL, Lu H, Makhijani VB, McDade KE, McKenna MP, Myers EW, Nickerson E, Nobile JR, Plant R, Puc BP, Ronan MT, Roth GT, Sarkis GJ, Simons JF, Simpson JW, Srinivasan M, Tartaro KR, Tomasz A, Vogt KA, Volkmer GA, Wang SH, Wang Y, Weiner MP, Yu P, Begley RF,
Rothberg JM: Genome sequencing in microfabricated high-density picolitre reactors. Nature 2005, 437:376-380.

4. Bentley DR, Balasubramanian S, Swerdlow HP, Smith GP, Milton J, Brown CG, Hall KP, Evers DJ, Barnes CL, Bignell HR, Boutell JM, Bryant J, Carter RJ, Keira CR, Cox AJ, Ellis DJ, Flatbush MR, Gormley NA, Humphray SJ, Irving $\sqcup$, Karbelashvili MS, Kirk SM, Li H, Liu X, Maisinger KS, Murray LJ, Obradovic B, Ost T, Parkinson ML, Pratt MR, Rasolonjatovo IM, Reed MT, Rigatti R, Rodighiero C, Ross MT, Sabot A, Sankar SV, Scally A, Schroth GP, Smith ME, Smith VP, Spiridou A, Torrance PE, Tzonev SS, Vermaas EH, Walter K, Wu X, Zhang L, Alam MD, Anastasi C, Aniebo IC, Bailey DM, Bancarz IR, Banerjee S, Barbour SG, Baybayan PA, Benoit VA, Benson KF, Bevis C, Black PJ, Boodhun A, Brennan JS, Bridgham JA, Brown RC, Brown AA, Buermann DH, Bundu AA, Burrows JC, Carter NP, Castillo N, Chiara E Catenazzi, Chang S, Neil CR, Crake NR, Dada OO, Diakoumakos KD, Dominguez-Fernandez B, Earnshaw DJ, Egbujor UC, Elmore DW, Etchin SS, Ewan MR, Fedurco M, Fraser LJ, Fuentes Fajardo KV, Scott FW, George D, Gietzen KJ, Goddard CP, Golda GS, Granieri PA, Green DE, Gustafson DL, Hansen NF, Harnish K, Haudenschild CD, Heyer NI, Hims MM, Ho JT, Horgan AM, Hoschler K, Hurwitz S, Ivanov DV, Johnson MQ, James T, Huw Jones TA, Kang GD, Kerelska TH, Kersey AD, Khrebtukova I, Kindwall AP, Kingsbury Z, Kokko-Gonzales PI, Kumar A, Laurent MA, Lawley CT, Lee SE, Lee X, Liao AK, Loch JA, Lok M, Luo S, Mammen RM, Martin JW, McCauley PG, McNitt P, Mehta P, Moon KW, Mullens JW, Newington T, Ning Z, Ling NB, Novo SM, O'Neill MJ, Osborne MA, Osnowski A, Ostadan O, Paraschos LL, Pickering L, Pike AC, Pike AC, Chris PD, Pliskin DP, Podhasky J, Quijano VJ, Raczy C, Rae VH, Rawlings SR, Chiva RA, Roe PM, Rogers J, Rogert Bacigalupo MC, Romanov N, Romieu A, Roth RK, Rourke NJ, Ruediger ST, Rusman E, Sanches-Kuiper RM, Schenker MR, Seoane JM, Shaw RJ, Shiver MK, Short SW, Sizto NL, Sluis JP, Smith MA, Ernest Sohna SJ, Spence EJ, Stevens K, Sutton N, Szajkowski L, Tregidgo CL, Turcatti G, Vandevondele S, Verhovsky Y, Virk SM, Wakelin S, Walcott GC, Wang J, Worsley GJ, Yan J, Yau L, Zuerlein M, Rogers J, Mullikin JC, Hurles ME, McCooke NJ, West JS, Oaks FL, Lundberg PL, Klenerman D, Durbin R, Smith AJ: Accurate whole human genome sequencing using reversible terminator chemistry. Nature 2008, 456:53-59.

5. Pandey $V$, Nutter RC, Prediger E: Applied Biosystems SOLiDTM System: Ligation-Based Sequencing. In Next-Generation Genome Sequencing: Towards Personalized Medicine.. 1 edition. Germany: Wiley-VCH;Janitz M. Weinheim 2011:29-41.

6. Korlach J, Bjornson KP, Chaudhuri BP, Cicero RL, Flusberg BA, Gray JJ, Holden D, Saxena R, Wegener J, Turner SW: Real-time DNA sequencing from single polymerase molecules. Methods Enzymol 2010, 472:431-455.

7. Blankenberg D, Von KG, Coraor N, Ananda G, Lazarus R, Mangan M, Nekrutenko A, Taylor J: Galaxy: a web-based genome analysis tool for experimentalists. Curr Protoc Mol Biol 2010, Chapter 19:Unit-21.

8. Goecks J, Nekrutenko A, Taylor J: Galaxy: a comprehensive approach for supporting accessible, reproducible, and transparent computational research in the life sciences. Genome Biol 2010, 11:R86.

9. Kent WJ, Sugnet CW, Furey TS, Roskin KM, Pringle TH, Zahler AM, Haussler D: The human genome browser at UCSC. Genome Res 2002, 12:996-1006.

10. Afgan E, Baker D, Coraor N, Chapman B, Nekrutenko A, Taylor J: Galaxy CloudMan: delivering cloud compute clusters. BMC Bioinformatics 2010, 11(Suppl 12):S4.

11. Mostafavi S, Ray D, Warde-Farley D, Grouios C, Morris Q: GeneMANIA: a real-time multiple association network integration algorithm for predicting gene function. Genome Biol 2008, 9(Suppl 1):S4.

12. Montojo J, Zuberi K, Rodriguez H, Kazi F, Wright G, Donaldson SL, Morris Q, Bader GD: GeneMANIA Cytoscape plugin: fast gene function predictions on the desktop. Bioinformatics 2010, 26:2927-2928.

13. Shannon P, Markiel A, Ozier O, Baliga NS, Wang JT, Ramage D, Amin N, Schwikowski B, Ideker T: Cytoscape: a software environment for integrated models of biomolecular interaction networks. Genome Res 2003, 13:2498-2504.

14. Barrett JC, Clayton DG, Concannon P, Akolkar B, Cooper JD, Erlich HA, Julier C, Morahan G, Nerup J, Nierras C, Plagnol V, Pociot F, Schuilenburg H, Smyth DJ, Stevens H, Todd JA, Walker NM, Rich SS: Genome-wide association study and meta-analysis find that over 40 loci affect risk of type 1 diabetes. Nat Genet 2009, 41:703-707.

15. Glessner JT, Bradfield JP, Wang K, Takahashi N, Zhang H, Sleiman PM, Mentch FD, Kim CE, Hou C, Thomas KA, Garris ML, Deliard S, Frackelton EC, 
Otieno FG, Zhao J, Chiavacci RM, Li M, Buxbaum JD, Berkowitz RI, Hakonarson H, Grant SF: A genome-wide study reveals copy number variants exclusive to childhood obesity cases. Am J Hum Genet 2010, 87:661-666.

16. Grant SF, Hakonarson H: Genome-wide association studies in type 1 diabetes. Curr Diab Rep 2009, 9:157-163.

17. Grant SF, Qu HQ, Bradfield JP, Marchand L, Kim CE, Glessner JT, Grabs R, Taback SP, Frackelton EC, Eckert AW, Annaiah K, Lawson ML, Otieno FG, Santa E, Shaner JL, Smith RM, Skraban R, Imielinski M, Chiavacci RM, Grundmeier RW, Stanley CA, Kirsch SE, Waggott D, Paterson AD, Monos DS, Polychronakos C, Hakonarson H: Follow-up analysis of genome-wide association data identifies novel loci for type 1 diabetes. Diabetes 2009, 58:290-295.

18. Hakonarson H, Grant SF, Bradfield JP, Marchand L, Kim CE, Glessner JT, Grabs R, Casalunovo T, Taback SP, Frackelton EC, Lawson ML, Robinson LJ, Skraban R, Lu Y, Chiavacci RM, Stanley CA, Kirsch SE, Rappaport EF, Orange JS, Monos DS, Devoto M, Qu HQ, Polychronakos C: A genomewide association study identifies KIAA0350 as a type 1 diabetes gene. Nature 2007, 448:591-594.

19. Hakonarson H, Qu HQ, Bradfield JP, Marchand L, Kim CE, Glessner JT, Grabs R, Casalunovo T, Taback SP, Frackelton EC, Eckert AW, Annaiah K, Lawson ML, Otieno FG, Santa E, Shaner JL, Smith RM, Onyiah CC, Skraban R, Chiavacci RM, Robinson LJ, Stanley CA, Kirsch SE, Devoto M, Monos DS, Grant SF, Polychronakos C: A novel susceptibility locus for type 1 diabetes on Chr12q13 identified by a genome-wide association study. Diabetes 2008, 57:1143-1146.

20. Hakonarson H, Grant SF: Genome-wide association studies in type 1 diabetes, inflammatory bowel disease and other immune-mediated disorders. Semin Immunol 2009, 21:355-362.

21. Hilner JE, Perdue LH, Sides EG, Pierce JJ, Wagner AM, Aldrich A, Loth A, Albret L, Wagenknecht LE, Nierras C, Akolkar B: Designing and implementing sample and data collection for an international genetics study: the Type 1 Diabetes Genetics Consortium (T1DGC). Clin Trials 2010, 7:S5-S32.

22. Qu HQ, Grant SF, Bradfield JP, Kim C, Frackelton E, Hakonarson H, Polychronakos C: Association analysis of type 2 diabetes Loci in type 1 diabetes. Diabetes 2008, 57:1983-1986.

23. Qu HQ, Grant SF, Bradfield JP, Kim C, Frackelton E, Hakonarson H, Polychronakos C: Association of RASGRP1 with type 1 diabetes is revealed by combined follow-up of two genome-wide studies. J Med Genet 2009, 46:553-554.

24. Qu HQ, Bradfield JP, Grant SF, Hakonarson H, Polychronakos C: Remapping the type I diabetes association of the CTLA4 locus. Genes Immun 2009, 10(Suppl 1):S27-S32.

25. Qu HQ, Bradfield JP, Belisle A, Grant SF, Hakonarson H, Polychronakos C: The type I diabetes association of the IL2RA locus. Genes Immun 2009, 10(Suppl 1):S42-S48.

26. Wang K, Baldassano R, Zhang H, Qu HQ, Imielinski M, Kugathasan S, Annese V, Dubinsky M, Rotter JI, Russell RK, Bradfield JP, Sleiman PM, Glessner JT, Walters T, Hou C, Kim C, Frackelton EC, Garris M, Doran J, Romano C, Catassi C, Van LJ, Guthery SL, Denson L, Piccoli D, Silverberg MS, Stanley CA, Monos D, Wilson DC, Griffiths A, Grant SF, Satsangi J, Polychronakos C, Hakonarson H: Comparative genetic analysis of inflammatory bowel disease and type 1 diabetes implicates multiple loci with opposite effects. Hum Mol Genet 2010, 19:2059-2067.

27. Wei Z, Wang K, Qu HQ, Zhang H, Bradfield J, Kim C, Frackleton E, Hou C, Glessner JT, Chiavacci R, Stanley C, Monos D, Grant SF, Polychronakos C, Hakonarson $\mathrm{H}$ : From disease association to risk assessment: an optimistic view from genome-wide association studies on type 1 diabetes. PLOS Genet 2009, 5:e1000678.

28. Diskin SJ, Hou C, Glessner JT, Attiyeh EF, Laudenslager M, Bosse K, Cole K, Mosse YP, Wood A, Lynch JE, Pecor K, Diamond M, Winter C, Wang K, Kim C, Geiger EA, McGrady PW, Blakemore Al, London WB, Shaikh TH, Bradfield J, Grant SF, Li H, Devoto M, Rappaport ER, Hakonarson H, Maris JM: Copy number variation at 1q21.1 associated with neuroblastoma. Nature 2009, 459:987-991.

29. Nguyen LB, Diskin SJ, Capasso M, Wang K, Diamond MA, Glessner J, Kim C, Attiyeh EF, Mosse YP, Cole K, Iolascon A, Devoto M, Hakonarson H, Li HK, Maris JM: Phenotype Restricted Genome-Wide Association Study Using a Gene-Centric Approach Identifies Three Low-Risk Neuroblastoma Susceptibility Loci. PLoS Genet 2011, 7:e1002026.
30. Wang K, Diskin SJ, Zhang H, Attiyeh EF, Winter C, Hou C, Schnepp RW, Diamond M, Bosse K, Mayes PA, Glessner J, Kim C, Frackelton E, Garris M, Wang Q, Glaberson W, Chiavacci R, Nguyen L, Jagannathan J, Saeki N, Sasaki H, Grant SF, Iolascon A, Mosse YP, Cole KA, Li H, Devoto M, McGrady PW, London WB, Capasso M, Rahman N, Hakonarson H, Maris JM: Integrative genomics identifies LMO1 as a neuroblastoma oncogene. Nature 2011, 469:216-220.

31. Bucan M, Abrahams BS, Wang K, Glessner JT, Herman El, Sonnenblick LI, Alvarez Retuerto Al, Imielinski M, Hadley D, Bradfield JP, Kim C, Gidaya NB, Lindquist I, Hutman T, Sigman M, Kustanovich V, Lajonchere CM, Singleton A, Kim J, Wassink TH, McMahon WM, Owley T, Sweeney JA, Coon H, Nurnberger Jl, Li M, Cantor RM, Minshew NJ, Sutcliffe JS, Cook EH, Dawson G, Buxbaum JD, Grant SF, Schellenberg GD, Geschwind DH, Hakonarson $\mathrm{H}$ : Genome-wide analyses of exonic copy number variants in a family-based study point to novel autism susceptibility genes. PLOS Genet 2009, 5:e1000536.

32. Gai X, Xie HM, Perin JC, Takahashi N, Murphy K, Wenocur AS, D'arcy M, O'Hara RJ, Goldmuntz E, Grice DE, Shaikh TH, Hakonarson H, Buxbaum JD, Elia J, White PS: Rare structural variation of synapse and neurotransmission genes in autism. Mol Psychiatry 2011.

33. Pinto D, Pagnamenta AT, Klei L, Anney R, Merico D, Regan R, Conroy J, Magalhaes TR, Correia C, Abrahams BS, Almeida J, Bacchelli E, Bader GD, Bailey AJ, Baird G, Battaglia A, Berney T, Bolshakova N, Bolte S, Bolton PF, Bourgeron T, Brennan S, Brian J, Bryson SE, Carson AR, Casallo G, Casey J, Chung BH, Cochrane L, Corsello C, Crawford EL, Crossett A, Cytrynbaum C, Dawson G, de JM, Delorme R, Drmic I, Duketis E, Duque F, Estes A, Farrar P, Fernandez BA, Folstein SE, Fombonne E, Freitag CM, Gilbert J, Gillberg C, Glessner JT, Goldberg J, Green A, Green J, Guter SJ, Hakonarson H, Heron EA, Hill M, Holt R, Howe JL, Hughes G, Hus V, Igliozzi R, Kim C, Klauck SM, Kolevzon A, Korvatska O, Kustanovich V, Lajonchere CM, Lamb JA, Laskawiec M, Leboyer M, Le CA, Leventhal BL, Lionel AC, Liu XQ, Lord C, Lotspeich L, Lund SC, Maestrini E, Mahoney W, Mantoulan C, Marshall CR, McConachie H, McDougle CJ, McGrath J, McMahon WM, Merikangas A, Migita O, Minshew NJ, Mirza GK, Munson J, Nelson SF, Noakes C, Noor A, Nygren G, Oliveira G, Papanikolaou K, Parr JR, Parrini B, Paton T, Pickles A, Pilorge M, Piven J, Ponting CP, Posey DJ, Poustka A, Poustka F, Prasad A, Ragoussis J, Renshaw K, Rickaby J, Roberts W, Roeder K, Roge B, Rutter ML, Bierut L, Rice JP, Salt J, Sansom K, Sato D, Segurado R, Sequeira AF, Senman L, Shah N, Sheffield VC, Soorya L, Sousa I, Stein O, Sykes N, Stoppioni V, Strawbridge C, Tancredi R, Tansey K, Thiruvahindrapduram B, Thompson AP, Thomson S, Tryfon A, Tsiantis J, Van EH, Vincent JB, Volkmar F, Wallace S, Wang K, Wang Z, Wassink TH, Webber C, Weksberg R, Wing K, Wittemeyer K, Wood S, Wu J, Yaspan BL, Zurawiecki D, Zwaigenbaum L, Buxbaum JD, Cantor RM, Cook EH, Coon H, Cuccaro ML, Devlin B, Ennis S, Gallagher L, Geschwind DH, Gill M, Haines JL, Hallmayer J, Miller J, Monaco AP, Nurnberger II Jr., Paterson AD, PericakVance MA, Schellenberg GD, Szatmari P, Vicente AM, Vieland VJ, Wijsman EM, Scherer SW, Sutcliffe JS, Betancur C: Functional impact of global rare copy number variation in autism spectrum disorders. Nature 2010, 466:368-372.

34. Wang K, Zhang H, Ma D, Bucan M, Glessner JT, Abrahams BS, Salyakina D, Imielinski M, Bradfield JP, Sleiman PM, Kim CE, Hou C, Frackelton E, Chiavacci R, Takahashi N, Sakurai T, Rappaport E, Lajonchere CM, Munson J, Estes A, Korvatska O, Piven J, Sonnenblick LI, Alvarez Retuerto Al, Herman El, Dong H, Hutman T, Sigman M, Ozonoff S, Klin A, Owley T, Sweeney JA, Brune CW, Cantor RM, Bernier R, Gilbert JR, Cuccaro ML, McMahon WM, Miller J, State MW, Wassink TH, Coon H, Levy SE, Schultz RT, Nurnberger J, Haines JL, Sutcliffe JS, Cook EH, Minshew NJ, Buxbaum JD, Dawson G, Grant SF, Geschwind DH, Pericak-Vance MA, Schellenberg GD, Hakonarson $\mathrm{H}$ : Common genetic variants on $5 \mathrm{p} 14.1$ associate with autism spectrum disorders. Nature 2009, 459:528-533.

35. Wang LS, Hranilovic D, Wang K, Lindquist IE, Yurcaba L, Petkovic ZB, Gidaya N, Jernej B, Hakonarson H, Bucan M: Population-based study of genetic variation in individuals with autism spectrum disorders from Croatia. BMC Med Genet 2010, 11:134.

36. Yang JJ, Cheng C, Devidas M, Cao X, Fan Y, Campana D, Yang W, Neale G, Cox NJ, Scheet P, Borowitz MJ, Winick NJ, Martin PL, Willman CL, Bowman WP, Camitta BM, Carroll A, Reaman GH, Carroll WL, Loh M, Hunger SP, Pui CH, Evans WE, Relling MV: Ancestry and pharmacogenomics of relapse in acute lymphoblastic leukemia. Nat Genet 2011, 43:237-241. 
37. McCarty CA, Chisholm RL, Chute CG, Kullo IJ, Jarvik GP, Larson EB, Li R, Masys DR, Ritchie MD, Roden DM, Struewing JP, Wolf WA: The eMERGE Network: a consortium of biorepositories linked to electronic medical records data for conducting genomic studies. BMC Med Genomics 2011, 4:13.

38. Rosenbloom ST, Denny JC, Xu H, Lorenzi N, Stead WW, Johnson KB: Data from clinical notes: a perspective on the tension between structure and flexible documentation. J Am Med Inform Assoc 2011, 18:181-186.

39. Wilke RA, Xu H, Denny JC, Roden DM, Krauss RM, McCarty CA, Davis RL, Skaar T, Lamba J, Savova G: The emerging role of electronic medical records in pharmacogenomics. Clin Pharmacol Ther 2011, 89:379-386.

40. Ross CJ, Visscher H, Sistonen J, Brunham LR, Pussegoda K, Loo TT Rieder MJ, Koren G, Carleton BC, Hayden MR: The Canadian Pharmacogenomics Network for Drug Safety: a model for safety pharmacology. Thyroid 2010, 20:681-687.

41. Dionne F, Mitton C, Rassekh R, Brooks B, Ross C, Hayden M, Carleton B: Economic impact of a genetic test for cisplatin-induced ototoxicity. Pharmacogenomics J 2011.

42. Visscher H, Amstutz U, Sistonen J, Ross CJ, Hayden MR, Carleton BC: Pharmacogenomics of cardiovascular drugs and adverse effects in paediatrics. J Cardiovasc Pharmacol 2011.

43. Newman M, Barabasi A-L, Watts DJ: The Structure and Dynamics of Networks. Princeton, NJ: Princeton University Press; 2006.

44. Fass C, Turtle B, Ginelli M: Six Degrees of Kevin Bacon. Plume Books; 1996.

45. Mostafavi $\mathrm{S}$, Morris Q: Fast integration of heterogeneous data sources for predicting gene function with limited annotation. Bioinformatics 2010, 26:1759-1765.

46. Hindorff LA, Sethupathy P, Junkins HA, Ramos EM, Mehta JP, Collins FS, Manolio TA: Potential etiologic and functional implications of genomewide association loci for human diseases and traits. Proc Natl Acad Sci U S A 2009, 106:9362-9367.

47. Roach JC, Glusman G, Smit AF, Huff CD, Hubley R, Shannon PT, Rowen L, Pant KP, Goodman N, Bamshad M, Shendure J, Drmanac R, Jorde LB, Hood L, Galas DJ: Analysis of genetic inheritance in a family quartet by whole-genome sequencing. Science 2010, 328:636-639.

doi:10.1186/1471-2105-12-S7-A

Cite this article as: Rouchka et al:: Proceedings of the Tenth Annual UTORNL-KBRIN Bioinformatics Summit 2011. BMC Bioinformatics 201112 (Suppl 7):A1.

\section{Submit your next manuscript to BioMed Central and take full advantage of:}

- Convenient online submission

- Thorough peer review

- No space constraints or color figure charges

- Immediate publication on acceptance

- Inclusion in PubMed, CAS, Scopus and Google Scholar

- Research which is freely available for redistribution

Submit your manuscript at www.biomedcentral.com/submit 